\section{LETTERS TO THE EDITOR.}

[The Editor does not hold himself responsible for opinions expressed by his correspondents. Neither can he undertake to return, or to correspond with the writers of, rejected manuscripts intended for this or any other part of NATURE. No notice is taken of anonymous communications.]

Cooperation between Scientific Libraries.

The note in Nature (February 15, p. 372) on Dr. T. Muir's paper in the Proceedings of the Royal Society of Edinburgh directs attention to a difficulty which, as you rightly say, affects many others than the mathematicians of Scotland. You adduce, for example, Wales; but may I, without giving offence to the Principality, venture to suggest that the metropolis itself has still better claims to dishonourable mention?

In the two sciences which chiefly appeal to me, geology and zoology, the difficulty mentioned by Dr. Muir has long presented itself forcibly, and there is a lengthy list of books that $I$ have been trying to see in vain, some of them for more than five years. They are, so far as I can ascertain, in none of the many libraries of this city. Naturally, the remedy suggested by Dr. Muir long ago presented itself to me, and I have lost no opportunity of urging it in conversation and in print. In view of your own recognition of the importance of the subject, I venture to ask you to reprint for a wider public the following paragraph from a paper contributed to the Museums Journal for April, 1902. After alluding to the cooperation between American libraries in the matter of cataloguing, and to the specialisation among the libraries of Chicago, I wrote :-

"The extraordinary difficulty that a student has, even in London, in seeing the literature of his subject-in fact, the impossibility, unless he is prepared to spend large sums of money on his private library-must have made many a one long for the day when the learned societies and other library authorities of London shall take this question of cooperation in hand. To what end is all this fuss about an international catalogue of scientific literature, with its elaborate mechanism and enormous expense, if, when the list of books is in his hands, it be still impossible for the student to refer to them? The amount of money annually spent by Government, through the libraries of the British Museum, the Education Department, the Patent Office, and the like, when joined with that spent by the great societies, such as the Royal, the Zoological, the Linnean, the Geographical, the Geological, with the College of Surgeons and other public bodies of like character, is surely enough, if properly administered, to buy the world's output of books each year; and far more than enough, if we remember that all publications of the United Kingdom go to the British Museum as a matter of course, and that the donation lists of many of these libraries are nearly as big as their purchase lists. If only the money could be pooled, and the purchases distributed according to some pre-arranged scheme among the various libraries; and if a joint catalogue were prepared, and kept up from month to month, showing not only the titles of books, periodicals, and papers, but the libraries in which they were to be found, then weary searching and fruitless wandering would no longer be the lot of the conscientious student. Even as things are, without so radical a reform as a redistribution of income, I feel sure that a conference of librarians, bent rather on furthering the interests of the reader than the pride of their own institutions, and armed with the necessary powers for cooperation, would soon lift London libraries out of the hopeless muddle that we now have to struggle with.'

I hope that now this subject has been taken up in your influential pages it will not be allowed to drop until those concerned have at least attempted the remedy.

\section{F. A. Batuer.}

\section{The Blondlot $n$-Rays}

IT would be interesting to know whether anyone has obtained success in repeating the latest experiment designed to show the objective reality of the $n$-rays, viz. that described by M. C. Gutton in Comptes rendus for January I 5 .

The writer has repeated M. Gutton's experiment with No. 1896 , voL. 737 much care, but has met with no more success in obtaining any positive result than he has in repeating a large number of M. Blondlot's own experiments, most of which he has essayed, in all cases with absolutely negative results, provided proper precautions were taken to avoid effects due to temperature and other extraneous causes of disturbance.

According to M. Gutton's experiment, the effect of the $n$-rays that proceed from a Nernst electric lamp upon a spark in a primary circuit is to diminish the brilliancy of another spark electrically induced in a secondary circuit by the primary discharge. Here one would suppose that the degree of brilliancy of the secondary spark can only be a matter of the amount of the electrical energy in the secondary circuit, but the writer finds that a very sensitive Duddell thermo-galvanometer, which would indicate a very small percentage of variation in the amount of this energy, shows no variation whatever.

A. A. Campbell Swinton.

66 Victoria Street, London, S.W., February 20.

\section{A 300.Year Climatic and Solar Cycle.}

IN June, I9o2, I made a few remarks on an apparent coincidence between sun-spot periods and longer periods of rainfall and famine in north China. Not being, in any sense, a meteorologist, I did not publish my conclusions except locally. In connection with a notice in the "Astronomical Column" of Nature, November 9 last (vol. 1xxiii. p. 38), they are of sufficient general importance to recall them. The notice in Nature is headed "A $300-y e a r$ Cycle in Solar Phenomena," and refers to a discussion in the Astrophysical Journal wherein Mr. H. W. Clough, of the Washington Weather Bureau, arrives at the conclusion that a 300-year cycle exists in solar and the allied terrestrial phenomena, and finds likewise an intermediate 36-year cycle, and supports both by a reference to various phenomena, such as aurora, periods of grape harvest, \&c.

In ${ }^{2} 877 \mathrm{Mr}$. A. Hosie, H.M. Consul at. Chengtu, published a paper in the Journal of the China Branch of the Royal Asiatic Society on droughts in China (new series, xii., 5I), extracted from Chinese records. As the records included all China, south as well as north, the tables did not at first sight exhibit any apparent periodicity. Some years after, on making a careful division into north and south, I was struck with a remarkable period of about 300 years, which seemed to me marked clearly in north China as an especial era of drought and famine. As, however, there seemed no reason for founding a new period, for the intercalation of which there was as yet no accumulated evidence, I proceeded no further with the subject. Mr. Hosie's paper went from the year 620 to 1643 , covering a period of 1023 years, and attached to it was another notice of sun-spots observed in China, also going back for some izoo years. The latter table, on account of the want of any observation instruments, is, of course, very fragmentary, but at the time I deduced from it without reference to European observations, which I had not by me, a probable period of 99 maxima in the 1920 years covered, which seemingly gave a mean of $1 x \cdot 08_{5}$ years, and which, produced to modern times, fell in sufficiently satisfactorily with the European records of the last century. Sir Norman Lockyer in rgor had also published observations bearing on a climatic curve of about six sun-spot periods, and commenting on all these I made the following remarks, which are entirely confirmative of Mr. Clough's findings, although deduced from such entirely different authorities.

"I now come to the long period or era which $\mathrm{Mr}$. Hosie's records seem to require. The first of these calling for notice seems to cover the three sun-spot periods $664^{-}$ 697 , though this is not so well marked as the others. The second covers the similar period from the maximum in 963 to that in 996 , when besides two years of drought in northern China, $96 \mathrm{I}$ and 962 , we find no less than twentythree years oct of the thirty-three characterised by excessive droughts in one or more of the northern provinces. The third covers the periods $1262-1295$, when, in addition to the antecedent year 1260 , there are noted twenty-one years of drought in the same provinces. The fourth is included between the spot maxima of I $_{56} \mathrm{I}$ and I594, and though not so marked as the second and third, yet ten years of 